\title{
PENGARUH ALAM PEMIKIRAN MITIS PADA LINGKUNGAN ALAM DAN PERMUKIMAN
}

\author{
Paulus Hariyono $^{1 a)}$ dan Veronica Wijayanti $\left.{ }^{1 b}\right)$ \\ Program Studi DIII Teknik LingkunganFakultas Teknik Universitas Pandanaran \\ J1. Banjarsari Barat I No. 1 Semarang \\ email ${ }^{1}$ : phariyono@yahoo.com \\ email ${ }^{2}$ : veronica_unpand@yahoo.co.id
}

\begin{abstract}
ABSTRAK
Alam dan manusia memiliki hubungan yang erat, dengan pola-pola tertentu. Dalam kurun waktu tertentu pola hubungan itu dapat berubah. Pola hubungan itu dapat dilihat pada alam pemikiran manusia. Menurut Peeursen (1988) ada tiga alam pemikiran manusia, yaitu 1) Alam Pemikiran Mitis, 2) Alam Pemikiran Ontologis, dan 3) Alam Pemikiran Fungsionalisme. Masingmasing memiliki pengaruh pada pola pengelolaan alam. Makalah ini akan membahas pengaruh alam pemikiran mitis manusia pada alam semesta. Manusia yang berpemikiran mitis biasanya banyak dijumpai pada masyarakat kuno. Masyarakat ini tunduk pada alam, karena alam selain menyediakan bahan pangan dan bahan sarana hidup, juga menyimpan kepercayaankepercayaan yang membuat mereka mengalami "ketegangan" dengan alam. Secara internal para anggota masyarakat memiliki rasa solidaritas yang tinggi, hubungannya erat. Keeratan hubungan sosial, kedekatan dengan alam, dan teknologi tradisional yang dimiliki ini berpengaruh pada pemanfaatan potensi alam sekitarnya pada tata ruang permukiman dan tata ruang rumah tinggal yang dekat dengan alam. Pola tata ruang permukiman dan rumah tinggal cenderung mengelompok dan sarat dengan unsur alam da bahan-bahan yang terkandung di alam. Secara keseluruhan mereka memiliki kehidupan yang bersifat natural, dekat dan tunduk dengan alam.
\end{abstract}

Kata kunci: alam pemikiran mitis, tunduk pada alam, permukiman mengelompok.

\section{PENDAHULUAN}

Lingkungan hidup menurut Undang-undang RI nomor 32 tentang Perlindungan dan Pengelolaan Lingkungan Hidup tahun 2009 adalah kesatuan ruang dengan semua benda, daya, keadaan, dan mahluk hidup, termasuk di dalamnya manusia dan perilakunya, yang mempengaruhi alam itu sendiri, kelangsungan perikehidupan dan kesejahteraan manusia serta makhluk hidup lainnya. Intisari lingkungan hidup adalah interaksi yang saling 
mengait antara mahluk hidup yang satu dengan yang lain; juga hubungan antara mahluk hidup yang bersifat biotik maupun benda abiotik.

\section{Interaksi di antara unsur-unsur di permukaan bumi yang} membentuk pola tertentu disebut ekosistem. Dalam UU no 32 Tahun 2009 disebutkan ekosistem adalah tatanan unsur lingkungan hidup yang merupakan kesatuan utuh menyeluruh dan saling mempengaruhi dalam membentuk keseimbangan, stabilitas, dan produktivitas lingkungan hidup.

Dengan demikian dalam lingkungan hidup unsur-unsur dimuka bumi, baik unsur biotik mapun abiotik saling berinteraksi membentuk sistem. Unsur biotik dan abiotik ini juga dimanfaatkan manusia untuk kepentingan hidupnya, seperti pembentukan permukiman dan rumah tinggal.

Dari latar belakang tersebut, dapat dirumuskan pertanyaan:

1. Bagaimana pemanfaatan sumber daya alam pada masa alam pemikiran mitis ?

2. Bagaimana pemanfaatan sumber daya alam untuk permukiman pada masa alam pemikiran mitis?

\section{KAJIAN TEORI}

Menurut Peursen (1988) salah satu alam pemikiran manusia adalah alam pemikiran mitis. Alam pemikiran ini merupakan awal kehidupan manusia, yaitu pada masa kuno.
Pada alam pemikiran mitis, hubungan antara manusia dan alam, baik alam metafisik, fisik, dan sosial, merupakan satu kesatuan yang era. Dominannya, manusia banyak bergantung pada alam. Pertama-tama, alam menyediakan mitos-mitos dan kepercayaan-kepercayaan; bahkan manusia merasakan dirinya terkepung oleh kekuatan-kekuatan alam lingkungan di sekitarnya.

Kedua, alam dan lingkungan sosialnya penuh dengan normanorma yang rigid. Apabila seorang warga melanggar norma tersebut, maka orang tersebut akan terkucilkan, bahkan diusir dari komunitasnya. Ketika mereka terkucilkan atau diusir, maka jiwanya akan terasa tercerabut dari kelompoknya, hidup seorang diri, dan akhirnya akan mengalami depressi.

Di alam pemikiran mitis, kekuasaan alam raya, sebagaimana yang diceritakan dalam mitosmitos suku bangsa primitif dirasa menekan dan mengusai sepak terjang manusia, karena alam menyediakan norma-norma yang rigid.

Dalam dunia mitis manusia belum merupakan seorang individu (subjek) yang utuh. Mereka dilanda oleh gambaran-gambaran dan perasaan-perasaan ajaib, seolaholah mereka diresapi oleh roh-roh dan daya-daya dari luar. Mereka terpesona oleh dunia ajaib ini yang menimbulkan teka-teki tentang kesuburan, kehidupan, kematian, pertalian kesukuan, persaudaraan, kebahagiaan, dan mala petaka. 
Peristiwa alam dan norma sosial yang terbentuk membuat mereka mengalami ketegangan, bahkan sampai ketakutan oleh peristiwaperistiwa di sekelilingnya serta tidak mungkin dapat bersikap dengan kepala dingin.

Bila sebuah gunung berapi meletus, atau terjadi banjir besar, atau terjadi gerhana matahari dan gerhana bulan, semua peristiwa alam ini membuat mereka bertanya-tanya.

Mereka memandang kejadian alam yang "menggetarkan" ini mempunyai hubungan erat dengan kekuasaan alam jagat raya sehingga segala petaka dan anugerah dihindari dan dimintakan kepada kekuatan dan kekuasaan alam jagat raya tersebut. Sebagai sarana komunikasi, dibentuklah upacara-upacara keselamatan kepada kekuatan alam adikodrati untuk menghentikan dan terhindar dari marabahaya bencana alam itu.

Maka dibuatlah patung leluhur maupun patung dewa-dewi sebagai representasi eksistensi alam jagat raya yang mampu mereka hayati. Lewat upacaraupacara manusia memintakan petunjuk persoalan hidupnya kepada leluhur dan bantuan kekuasaan alam jagat raya.

Irama tari-tarian yang bertalu-talu membuat mereka kerasukan dalam menghayati kehadiran alam jagat raya untuk diajak berkomunikasi, dan dimintakan keselamatan.

Demikian juga kesuburan tanaman dimintakan perlindungan dari kekuasaan alam jagat raya melalui upacara-upacara. Untuk menjaga kesuburan tanaman padi di sawah masyarakat Jawa memohon kepada Dewi Sri.

Peristiwa

kelahiran, kematian, dan keselamatan yang berkaitan dengan eksistensi peristiwa kehidupan manusia dimintakan dan dihindari melalui upacara-upacara. Penghormatan terhadap para leluhur, lambanglambang pohon kehidupan, air/tirta, topeng yang mempesonakan, menunjukkan rasa hormat, penuh getaran ketakutan terhadap dasar eksistensinya sendiri sehingga menumbuhkan rasa takut terhadap kekuatan itu yang akan menentukan kesejahteraan hidup manusia. Semua lambang itu merupakan "jendela-jendela" yang membuka pandangan terhadap dunia transenden.

Bahkan kepemimpinan dan kerukunan dalam suku itu baru mungkin atas dasar mitos-mitos. Kaisar Jepang dimitoskan sebagai keturunan Dewa Matahari yang mempersatukan bangsa Jepang. Raja-raja pada jaman dahulu umumnya dimitoskan memiliki kekuatan ataupun keturunan dari dewa. Dengan cara inilah masyarakat pada masa lalu dapat disatukan. Hubungan sosial antar manusia pun merupakan satu kesatuan keterikatan yang saling bergantungan. Kebersamaan dan keseragaman merupakan kata kunci hubungan sosial di antara warga. 


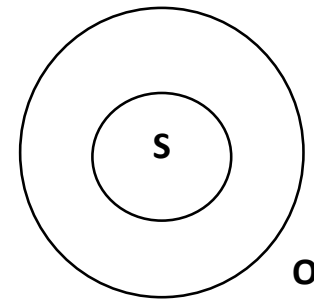

Gambar 1. Alam Pemikiran Mitis: manusia (S) terkepung oleh lingkungan $(\mathrm{O})$, baik lingkungan alam metafisik, sosial, dan fisik (Sumber : Hariyono dan Wijayanti, Neo Teknika, Desember 2018).

Sekalipun tampak tidak masuk akal dari sudut pandangan orang modern, menurut Peeursen (1988) mitos-mitos yang dominan menghantui masyarakat alam pemikiran mitis, memiliki fungsi:

1) Mitos memberikan kesadaran kepada manusia bahwa sebenarnya ada kekuatankekuatan ajaib di dunia ini. Bahkan manusia modern pun melalui agama-agamanya memiliki mitos tersendiri, tentang Tuhan-nya, tentang bagaimana alam ini terjadi, dan bagaimana dengan surga dan neraka itu.

2) Mitos membantu masyarakat memperoleh keinginankeinginan hidupnya. Misalnya, pada musim semi, bila ladangladang digarap, diceritakan sebuah dongeng, dinyanyikan lagu-lagu pujian maupun diperagakan sebuah tari-tarian. Lewat peristiwa ini para dewadewi dilihatnya mulai menggarap sawah dan memperoleh hasil yang berlimpah, sehingga mitos dapat memberikan jaminan bagi kelangsungan hidup masyarakatnya.

3) Melalui mitos dapat dijelaskan tentang terjadinya alam beserta isinya, juga tentang kelahiran manusia dan para dewa-dewi, serta bagaimana dewa-dewi berperan dalam hidup seharihari manusia.

Kedekatan pada alam menunjukkan bahwa segala kebutuhan hidup masyarakatnya diambil dari alam, baik itu membangun rumah tinggal, bahan makanan maupun pengobatan. Dapat dikatakan seratus persen bahan bangunan rumah diambil dari alam, seperti atap yang terbuat dari daun rumbia, kayu, pengikatnya dari serabut, dan bahan bebatuan.

Sekalipun memiliki alam pemikiran mitis yang penuh kepercayaan-kepercayaan, masyarakat ini memiliki teknologi tersendiri, yang disebut teknologi tradisional. Mereka membuat teknologi untuk memenuhi kebutuhan hidupnya dari bahanbahan setempat. Secara teknologi rumah adat Sasak di Lombok, disebutkan memiliki keunggulan tahan gempa (google, diakses 26 Juni 2019).

\section{METODOLOGI}

Dalam membahas makalah ini digunakan metode penelitian yang bersifat kualitatif. Menurut Sugiyono (2014:1) dalam metode kualitatif ini, realita sosial dipandang sebagai sesuatu yang 
holistik, utuh, menyeluruh, kompleks, dinamis, dan penuh dengan makna.

Metode penelitian kualitatif digunakan untuk meneliti pada kondisi obyek yang bersifat alamiah (naturalistik). Sebagai lawannya adalah bersifat eksperimen.

Lebih lanjut Sugiyono (2014:1) menyebutkan, analisis data kualitatif dilakukan secara trianggulasi (gabungan), bersifat induktif. Hasil penelitian kualitatif lebih menekankan makna. Data kualitatif adalah data informasi yang berbentuk kalimat verbal. Analisa kualitatif adalah analisa berdasarkan logika verbal.

Menurut Hadi (1990:3), salah satu jenis penelitian adalah penelitian kepustakaan. Teori yang ada dianalisa dengan kondisi nyata masyarakat. Analisa antara teori dan kondisi masyarakat diperoleh suatu pernyataan yang hasilnya diperoleh melalui suatu kesimpulan (bersifat induktif).

Jadi teori dan data yang ada dilakukan pemahaman tentang makna. Makna antara unsur yang satu dengan yang lain dihubungkan secara rasional, dan merupakan rangkaian makna yang bersifat holistik, dan disimpulkan secara induktif.

Kepustakaan dominan yang digunakan dalam penelitian ini adalah buku karya Van Peursen dengan judul "Strategi Kebudayaan". Salah satu hal utama yang disebut adalah tentang alam pemikiran mitis yang banyak dijumpai pada masyarakat kuno.
Alam pemikiran manusia ini ternyata memiliki pengaruh pada manusia jaman kuno dalam memandang alam dengan relasirelasi tertentu, sehingga diperoleh suatu kesimpulan tertentu. Dengan demikian metode analisis yang digunakan adalah metode kualitatif, dilakukan secara trianggulasi (gabungan) dan bersifat induktif.

\section{PEMBAHASAN}

\section{Alam Dekat dengan Manusia}

Seperti telah diuraikan pada tinjauan pustaka, dalam alam pemikiran mitis, manusia terkurung oleh lingkungan di sekitarnya. Unsur-unsur di permukaan bumi dilihat memiliki kekuatan yang dapat mempengaruhi hidup manusia, entah itu tanah, hewan, maupun tumbuh-tumbuhan. Tanah tertentu dipercaya memberikan "kesuburan" maupun "kegersangan" tersendiri bagi hidup manusia. Demikian pula jenis-jenis hewan dan tumbuhtumbuhan. Situasi lingkungan ini membuat manusia terkungkung, dengan kata lain manusia tunduk pada alam beserta lingkungannya.

\section{Pemanfaat Bahan Alam untuk Permukiman}

Pada masa alam pemikiran mitis, alam menjadi perhatian untuk dipelihara dengan sebaikbaiknya. Alam dengan tanaman, hutan beserta isinya merupakan sentra kepercayaan dalam alam pemikiran mitis. Pada masa ini jumlah penduduk masyarakat masih sedikit, tetapi hubungan kemasyarakatannya erat. Keeratan 
hubungan ini, berakibat permukimannya cenderung mengelompok.

Pola permukiman tersebut sering disebut sebagai permukiman adat. Sebagai contoh, permukiman adat Lombok, Irian Jaya, Minangkabau, permukiman suku masyarakat Naga (Banten). Pola permukimannya tersusun secara mengelompok. Pada permukiman berkelompok ini biasanya dikelilingi dengan tanaman dan pepohonan yang lebat, yang memberi kesan dekat dengan alam.

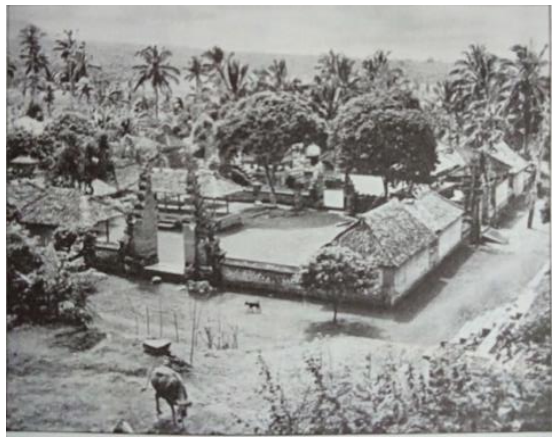

Gambar 2. Alam masih dekat dengan permukiman pada zaman kuno (Mangunwijaya, 1995).

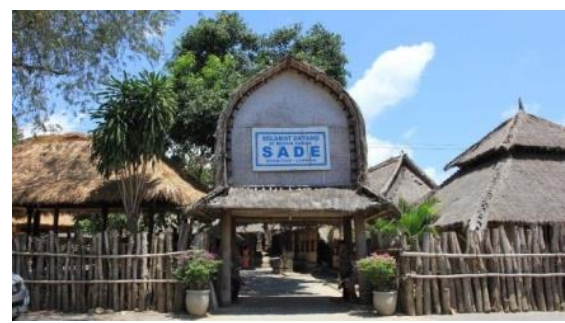

Gambar 3. Alam masih dekat pada permukiman masyarakat Sasak, Lombok (Google, 22 Juni 2019)
Rumah tinggal terbuat dari bahan alam sekitarnya, sebagai misal rumah adat Maluku. Atap terbuat dari dedauan, kerangka rumah dari bahan bambu dan kayu. Tali pengikat dari serabut. Penyambungan kayu pada siku dapat terbuat dari patok kayu.

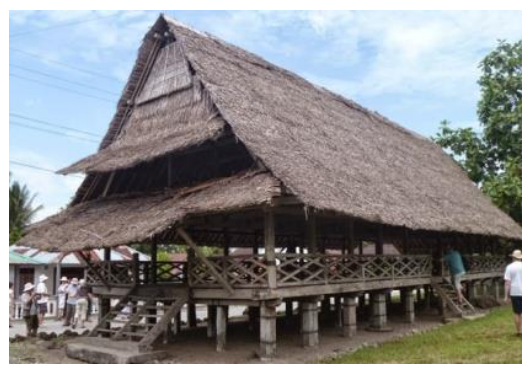

Gambar 5. Bahan baku berasal dari alam sekitarnya, digunakan untuk membangun rumah adat maluku (baileo)

(Sumber: http://adat-tradisional. blogspot.com/2016/10/rumah-adatmaluku-rumah-baileogambar.html)

Bahkan pada rumah adat suku Sasak di Pulau Lombok, lantai rumah terbuat dari campuran tanah liat dan kotoran kerbau. 


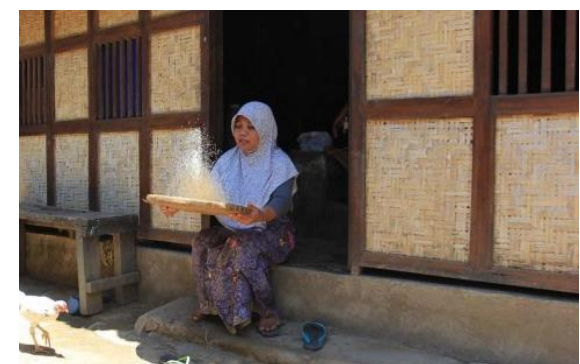

Gambar 6. Campuran kotoran kerbau dan tanah liat yang dikeringkan digunakan untuk membuat lantai pada rumah adat Sasak, di Pulau Lombok (Sumber: http://adat-tradisional.

blogspot.com/2016/10/rumah-adatsasak).

\section{Keeratan Hubungan Sosial}

Masyarakat pada alam pemikiran mitis yang homogen dan tunduk pada alam, berakibat solidaritas masyarakatnya tinggi. Hubungan di antara anggota masyarakatnya erat, sehingga interaksi sosialnya juga erat. Akibatnya pergaulan hidup di antara anggota masyarakat sering terjadi dalam hidup sehari-hari.

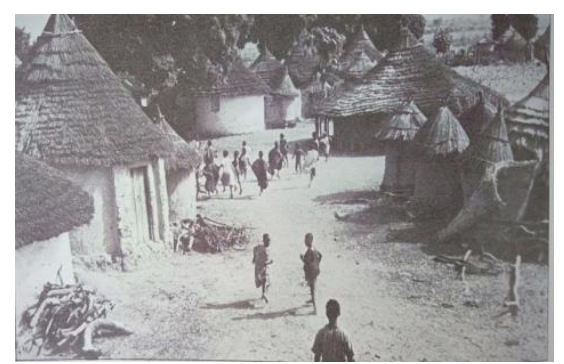

Gambar 4. Kehidupan sosial masyarakat kuno yang erat pada jaman kuno (Mangunwijaya, 1995).

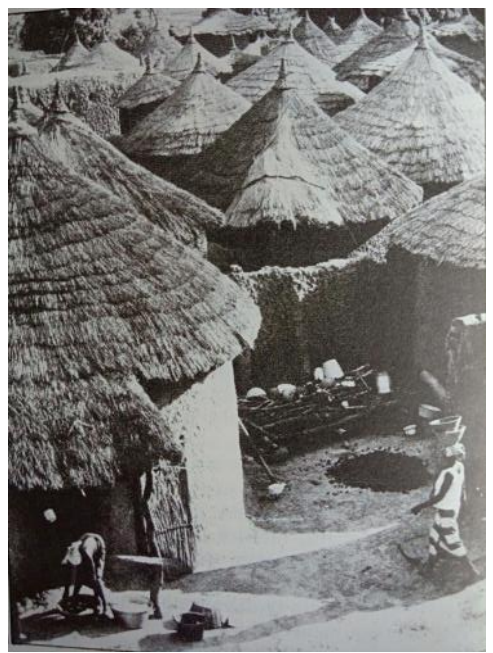

Gambar 7. Permukiman rumah adat saling berdekatan, mengelompok, masih dipenuhi dengan pepohonan yang lebat (Mangunwijaya, 1995).

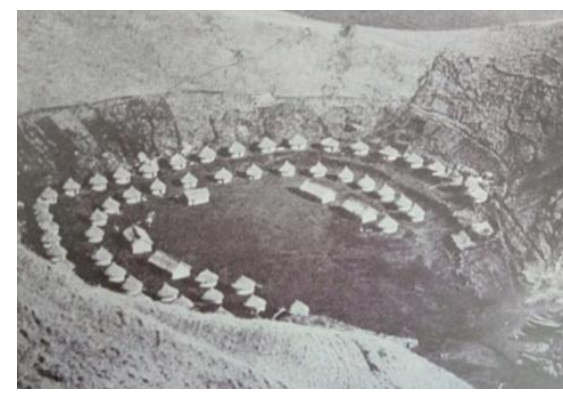

Gambar 8. Keeratan hubungan sosial berakibat pada pola permukiman yang mengelompok.

\section{PENUTUP}

Perjalanan hidup manusia berlangsung lama, dari abad kuno hingga abad modern. Pada abad kuno alam beserta isinya merupakan bagian yang tak terpisahkan dari hidup masyarakatnya.

Alam beserta isinya merupakan gantungan hidupnya. 
Hutan dengan kekayaan kayu dan dedaunan beserta tanaman lain merupakan bahan untuk menopang sarana hidup, pembangunan rumah tinggal, makanan, dan pengobatan.

Di dalam alam juga terkandung materi untuk kepercayaan hidup masyarakatnya, yang berfungsi untuk mengarahkan hidupnya.

Alam ternyata berjalan telah lama sekali. Sejak zaman kuno, ketika populasi manusia masih sedikit, sekian ribu tahun sebelum masehi hingga era modern zaman sekarang. Di era zaman kuno, ketika manusia dominan mengalami alam pemikiran mitis, dalam mengintervensi alam sangat minim sekali, sehingga tidak mengundang persoalan ekologi, bahkan mereka cenderung tunduk pada alam.

Pada alam pemikiran mitis, alam menjadi tumpuan hidup secara psikis maupun fisik. Secara psikis, alam mengarahkan hidup masyarakatnya melalui kepercayaan dan mitos. Kebutuhan hidup sehari-hari dari makanan, pengobatan, dan membuat permukiman dan rumah tinggal dipenuhi dari alam.

\section{DAFTAR PUSTAKA}

Hadi, S., 1990, Metodologi Reseach, Fakultas Psikologi UGM, Yogyakarta.

Hariyono, P \& Wijayanti, V. 2018. Relasi Manusia pada Alam dalam Jurnal Neo Teknika Vol. 4 No. 2. Semarang: Fakultas Teknik Universitas Pandanaran.
Peeursen, V., 1988,Strategi Kebudayaan,Kanisius, Yogyakarta.

Sugiyono, S., 2014, Memahami Penelitian Kualitatif, Alfabeta, Bandung.

Undang-Undang RI nomor 32 tentang Perlindungan dan Pengelolaan Lingkungan Hidup Tahun 2009.

http://adat-tradisional.

blogspot.com/2016/10/rumah-adatmaluku-rumah-baileo-gambar.html

http://adat-tradisional.

blogspot.com/2016/10/rumah-adatsasak). 